\section{Old World Revisited}

old World Monkeys (Evolution, Systematics and Behaviour). Edited by J. R. Napier and P. H. Napier. Pp. xvi +660 . (Academic Press: New York and London, 1970.) £9.50.

THIS volume contains nineteen contributions from a symposium in BurgWartenstein (July 1969), sponsored by the Wenner Gren Foundation. The primary intention was provision of a basis for revising the systematics of Old World monkeys (superfamily Cercopithecoidea), and that aim has been admirably fulfilled. The papers provide an excellent source of up to date information on a number of key topics. In particular, it is invaluable to find in one volume a review of the fossil history of the Old World monkeys (Simons), a concise survey of biochemical aspects of monkey evolution (Barnicot and Wade ; Sarich), an account of the oft neglected area of Sundaland (Medway), a series of papers on the behaviour of forestliving monkey species (Lowe's GuenonBourlière et al.; Drill-Gartlan ; Gray Langurs-Ripley), a fascinating account of cross-species modification of social behaviour in baboons (Kummer et $a l$. ), and an annotated classification (Thorington and Groves). Among the behavioural papers, Struhsaker's account of the relevance of Cercopithecus vocalisations for classification is particularly noteworthy. Academically, the overall product is a highly useful and stimulating book, for which tribute should be paid to the sponsors and the editors. This book should prove to be essential for anyone concerned with Old World monkeys and their evolution.

Interest in biochemical aspects of Primate evolution is growing rapidly, and outsiders will find the balanced account provided by Barnicot and Wade both readable and informative. Evolution operates through modifications in the structure of DNA, and such changes can be directly expressed in protein structure. Ideally, an analysis of amino-acid sequences in various proteins should provide highly reliable data on evolutionary change. Actual sequencing is rare, however, and most workers estimate amino-acid change largely with electrophoretic techniques (Barnicot and Wade) or through immunological cross-reaction (Sarich). In spite of the limitations of such techniques, Sarich claims to be able to provide an absolute evolutionary time scale, given calibration of one point from the fossil record. It is unfortunate that he should have selected an extremely questionable date (that of the divergence of Cercopithecoidea and Hominoidea) for calibration, and that he should have proceeded to a controversial dating for the divergence of apes and man, where the fossil record is comparatively good. As Thorington hints in his introduction, new techniques of this kind are best tested by comparison with existing classifications, rather than vice versa. Eventually, biochemical data will provide a precise tool for investigating evolutionary relationships; but there are still many difficulties of interpretation to be mastered. Nonetheless, it does emerge quite clearly from both biochemical contributions that the New World monkeys are probably not separately derived from prosimian ancestors; although the date of divergence is not clear, it seems obvious that there was a specific stock which gave rise to all the monkeys and the apes.

A review of the fossil history of the Old World monkeys has long been overdue, and Simons does much to clarify a somewhat confused situation. There is, however, one conspicuous omission. Simons states that Apidium should be classified within the Cercopithecidae, and he has also suggested that Oreopithecus is a close relative of Apidium (Simons, E. L., Scientific American, 211, 50; 1964). Since this implies that Oreopithecus is an Old World monkey (contrary to Hürzeler's interpretation), adequate treatment of this fossil would have been welcome. Simons also gives the impression that available fossils are sufficient for zoogeographical interpretation, which is not the case. His apparent conflict with the views expressed in Napier's stimulating discussion of palaeoecology and evolution should be viewed in this light.

Typographically, this book does not do justice to its academic importance. The mixture of (sometimes inaccurate) typescript with neat printing is unpleasing, and it is disruptive to find the figures and tables grouped at the ends of the papers. There are many typing errors, one of which has led to the surprising statement in Ripley's paper that "The food of the grey langurs consists primarily of termite clay" (page 486). Even on the book jacket, there is a reference to "etholologists" (?). Presumably, the justification for this layout could be that of economy; but such economy is not evident in the high price quoted.

R. D. MARTIN

\section{Drugs in Confusion}

Drug Dependence. Edited by Robert T. Harris, William M. McIsaac and Charles R. Schuster Jr. (Advances in Mental Science II.) Pp. xiv +342 . (University of Texas: Austin and London, November 1970. Published for the Faculty for Advanced Studies of the Texas Research Institute for Mental Sciences.) $95 s$.

IN spite of the title, this is a miscellaneous collection of papers given at the "second annual symposium sponsored by the Texas Research Institute of Mental Science". The date of the meeting is nowhere mentioned but from internal evidence it seems to have been in the first half of 1968. There are twentyfour contributions of varying quality, arranged under the general headings "Biological Aspects" (eight papers); "Pharmacological Aspects" (three); "Behavioral Aspects" (five); "Therapeutic Programmes for Drug Dependence" (five) and "Social Aspects" (three). If the first group is redistributed (drug dependence is a biological phenomenon), the last sub-divided into "Penal Aspects" and "Social Aspects", and one or two of the most obviously misclassified papers helped into more appropriate company, we get pharmacology, nine; behaviour, seven; treatment, two; law and punishment, four, and society, two.

This kind of "balance" is fairly representative of collections of this kind, and it may well be due in part to the difficulty of collecting hard data in soft areas; although it should be pointed out that "hard" is not necessarily synonymous with "reliable" or even "objective", and is seldom coincidental with "relevant". But of course the hard scientists always have the best of that argumentto paraphrase the little girl (or, some say, the old lady), they can and do claim "you can't tell if it's relevant if you don't give me a grant". Another kind of imbalance is more worrying, however, and it is hard to say if it is exaggerated or lessened by mixing scientists from different disciplines together in this way. I mean the trespassing of scientists, 